\title{
EVRE I GERM HÜCRELI OVER TÜMÖRLERINDE NÜKS GELIŞIMINE ETKI EDEN FAKTÖRLER
}

\author{
FACTORS AFFECTING RECURRENCE DEVELOPMENT IN STAGE I GERM CELL OVARIAN TUMORS
}

\author{
Varol GÜLSEREN ${ }^{1}$, Mustafa KOCAER ${ }^{2}$, İsa Aykut ÖZDEMiR ${ }^{3}$, Mehmet GÖKÇÜ4 ${ }^{4}$, Muzaffer SANCI ${ }^{4}$, \\ Kemal GÜNGÖRDÜK ${ }^{5}$ \\ ${ }^{1}$ Mersin Şehir Hastanesi, Kadın Hastalıkları ve Doğum Bölümü \\ ${ }^{2}$ Izmir Tepecik Eğitim ve Araştırma Hastanesi, Kadın Hastalıkları ve Doğum Bölümü \\ ${ }^{3}$ Bakırköy Sadi Konuk Eğitim ve Araştırma Hastanesi, Jinekolojik Onkoloji Bölümü \\ ${ }^{4}$ İzmir Tepecik Eğitim ve Araştırma Hastanesi, Jinekolojik Onkoloji Bölümü \\ ${ }^{5}$ Mersin Üniversitesi Tıp Fakültesi, Jinekolojik Onkoloji Bölümü
}

öz

AMAÇ: Evre I malign germ hücreli over tümörü (MGHOT) hastalarında nüks geliş̧imine ve hastalıksız sağkalım süresine etki eden faktörlerin araştırılmasıdır.

GEREÇ VE YÖNTEM: Tepecik Eğitim Araştırma hastanesi jinekoloji onkoloji kliniğinde Ocak 1998 - Ocak 2016 tarihleri arasında MGHOT tanısını alan ve tedavi uygulanan 27 hastanın kayıtları retrospektif olarak incelendi. Prognostik faktörlerden CA125 değeri $>35$, yaş $\geq 24$, lenf nodu örneklemesi yapılmayan hastalar, kemoterapi verilmeyen hastalar, tümör boyutu $>10 \mathrm{~cm}$ olan ve kapsül invazyonu olan hastalar değerlendirildi.

BULGULAR: Çalışamaya 27 MGHOT hastası alındı. Hastaların $7(\% 25,9)$ tanesi sadece ameliyat olurken, $20(\% 74,1)$ hasta ameliyat sonrası adjuvan kemoterapi aldı. 20 hastanın tamamı biliomisin, etoposid ve sisplatin (BEP) protokolünü aldı. Hastaların 4 (\%14,8) tanesinde nüks geliști. Prognostik faktörlerden yüksek CA125 (>35) değeri ve kemoterapi almayan hastaların univaryant lojistik regresyon analizine göre nüks riskini arttırdığı görüldü. Hastalıksız sağkalım süresine etki eden risk faktörü Cox-regresyon analizine göre yüksek CA125 ve kemoterapi almayan hastalardı.

SONUÇ: Evre I malign germ hücreli over tümörüne sahip hastalarda yüksek CA125 değeri ve adjuvan kemoterapi verilmemesinin nüks gelişimini anlamlı derecede arttırdığı ve hastalıksız sağkalımı kısalttığı görülmektedir.

ANAHTAR KELIMELER: Germ hücreli tümörler; Over tümörleri; Over kanseri; Overin germ hücreli tümörleri

Geliş Tarihi / Received: 30.06 .2018

Kabul Tarihi / Accepted: 11.12.2018

Yazışma Adresi / Correspondence: Uzm.Dr.Varol GÜLSEREN

Mersin Şehir Hastanesi, Kadın Hastalıkları ve Doğum Bölümü

E-mail: varolgulseren@dr.com

Orcid No: 000-0002-0779-8305

\section{ABSTRACT}

OBJECTIVE: To investigate the factors affecting recurrence development and time of disease-free survival in stage I malignant germ cell over tumor (MGCOT) patients.

MATERIAL AND METHODS: Records of 27 patients who received MGCOT diagnosis between January 1998 and January 2016 in the gynecology oncology clinic of Tepecik Training and Research Hospital were reviewed retrospectively. Patients with CA125 value $>35$, age $\geq 24$, patients without lymph node sampling, patients without chemotherapy, patients with tumor size $>10 \mathrm{~cm}$, and capsule invasion were evaluated from prognostic factors.

RESULTS: We received 27 MGCOT patients to study. Seven $(25.9 \%)$ of the patients had only surgery and 20 (74.1\%) patients received adjuvant chemotherapy after surgery. All 20 patients received bleomycin, etoposide and cisplatin (BEP) protocol. Four patients (14.8\%) developed recurrence. Patients with high CA125 (> 35) values and those who did not receive chemotherapy from prognostic factors were found to increase risk of relapse according to univariant logistic regression analysis. The risk factors affecting the time of disease-free survival were high CA125 and patients who did not receive chemotherapy according to Cox-regression analysis.

CONCLUSIONS: In patients with stage I malignant germ cell over tumor, high CA125 values and no adjuvant chemotherapy appear to significantly increase recurrence development and shorten disease-free survival.

KEYWORDS: Germ cell tumors; Ovarian tumors; Ovarian cancer; Ovarian germ cell tumors 


\section{GíRiş}

Malign germ hücreli over tümörleri (MGHOT) nadir görülür ve ovaryan malignitelerin \%23'ünü oluşturmaktadır $(1,2)$. İlk 2 dekadda görünen over tümörlerinin \%70'i germ hücre kaynaklıdır ve yaklaşık üçte biri maligndir (2). Bu tümörler genellikle adelösan ve genç reprodüktif dönemdeki bayanlarda görünmektedir. Germ hücreli tümör gelişimi için bilinen en önemli risk faktörü primer amenore ve pubertenin gecikmesine neden olan gonadal disgenezilerdir (1). Dünya sağlık örgütünün sınıflandırmasına göre germ hücreli tümörleri; primitif germ hücreli over tümörleri, bifazik veya trifazik teratomlar ve monodermal teratomlar gruplarına ayrilır $(1,2)$.

Tedavide fertilite koruyucu cerrahi hastaların adelösan veya reprodüktif yaşların başlarında olması nedeni ile tercih edilen prosedürdür (1). Diğer overi normal görünenlerde unilateral ooferektomi işlemi uygulanır. Disgerminomlar hariç germ hücreli tümörlerin \%95'i unilateraldir ve uterusa yayılım nadirdir $(3,4)$. Özellikle disgerminomlarda \%10-15 bilateral tutulum olabilir ancak yine de fertilite koruyucu işlem için çaba sarfedilmelidir (1). Karşı taraf overi normal görünen hastalara, rutin biyopsi yapılmasından kaçınılmalıdır (2). Yapışıklık ve ovaryan yetmezlik gibi nedenler ile ilerde infertilite nedeni olabilir (2).

Cerrahi evreleme peritoneal sitoloji örneği, şüpheli peritoneal alanlardan biyopsi, retroperitoneal lenfadenektomi ve infrakolik omentektomiyi içermektedir (2). Daha önceki yapılan çalışmalarda, malign germ hücreli over tümörü olan hastaların \%18'inde lenf nodu tutulumu olduğu gösterilmiştir. Lenf nodu tutulumunun sağkalımı negatif yönde etkilediği saptanmıştır. Tam evreleme yapılmadan evre I olarak düşünülen ve kemoterapi verilmeyen hastaların, \%40'ında nüks geliştiği görülmüştür. En sık kulIanılan kemoterapi rejimi bliomisin, etoposid ve sisplatin (BEP) kombine tedavisidir (1). Genellikle 3 veya 4 kür verilir. Çoğunlukla tamamen tümör rezeke edildi ise 3 , rezidü tümörü olanlarda 4 kür tedavi verilir.

Bu çalışmanın amacı, evre I MGHOT hastalarında nüks gelişimine ve hastalıksız sağkalım süresine etki eden faktörlerin araştırılmasıdır.

\section{GEREÇ VE YÖNTEM}

Tepecik Eğitim Araştırma hastanesi jinekoloji onkoloji kliniğinde Ocak 1998 - Ocak 2016 tarihleri arasında MGHOT tanısını alan ve tedavi uygulanan 27 hastanın kayıtları retrospektif olarak incelendi. Çalışmada yer alan MGHOT olan hastaların alt tipleri; disgerminom, yolksak tümörü (endodermal sinüs tümörü), miks (yolk sak + embriyonal karsinom) ve immatür teratomlardır. Çalışmaya dahil edilmeme kriterleri: takiplere hiç gelmemiş olmak, evre II-IV tümörü olanlar ve eşlik eden diğer jinekolojik veya non-jinekolojik malignitenin olması olarak belirlendi.

Hastaların verileri dosyalarından geriye dönük olarak analiz edildi. Hastalara yapılmış olan görüntüleme yöntemleri ve patoloji sonuçları değerlendirilerek evrelemeleri yapıldı. Evreleme uluslararası jinekoloji ve obstetri federasyonu (FIGO) 2014 cerrahi evreleme sistemine göre yapıldı. Evre IA tümör bir overde sınırlı kapsül intakt, yüzeyde tümör yok ve peritoneal sitoloji örneği benign olarak tanımlandı. Evre IB'de tümör iki overde ve diğer özellikler evre IA ile aynı. Tümör bir veya iki overde sınırlı ve bunun yanında cerrahi yayılım varsa evre IC1, ameliyattan önce tümör kapsülünün rüptürü veya over yüzeyinde tümör olması evre IC2, peritoneal sitoloji örneği veya asit örneğinde malign hücrelerin olması evre IC2 olarak tanımlandı. 2014'den önce gelen hastaların evreleri 2014 FIGO sistemine göre revize edildi.

Evre dışında hasta yaşı, parite sayısı, tedavi şekli, ameliyatta yapılan işlemler, tümör boyutu, biyopside histolojik tipi ve kapsül invazyonu varlığı incelendi. Nüks geliş̧imi ve tedavisi, hastalıksız sağkalım (DFS) ve toplam sağkalım (OS) süresi, kemoterapi tipi, kür sayısı ve dozu, radyoterapi tipi ve dozu analiz edildi. Labaratuvar sonuçlarından ameliyat öncesi kanser antijen (CA) 125, LDH, AFP ve $\beta$ HCG sonuçları raporlandı. Kayıtlardan primer tedavide ameliyat anında veya sonrasında ve kemoterapi sonrasında meydana gelen komplikasyonlar araştırıldı. Yapılan tamamlayıc ameliyatlar ve tipleri dosyalardan değerlendirildi. Hastalar 12 ay ile 180 ay arasında takip edildi. Hastaların takipten çıkma şekilleri, ölüm veya takibi kendileri terk etmeleri şeklinde idi. 
DFS tanı anından nüks gelişene kadar veya son kontrole geldiği süreye kadar olan zaman aralığı olarak alındı. OS süresi tanı anı ile son muayene edildiği tarihe veya ölüm tarihine kadar olan zaman aralığı olarak alındı. Sağkalım analizleri Kaplan-Meier metodu ile yapıldı ve sonuçlar log-rank testi ile karşılaştırıldı. Risk faktörleri değerlendirilirken lojistik regresyon analizi kullanıldı. Sağkalıma etki eden prognostik faktörler karşılaştırılırken Cox-regresyon analizi kullanıldı. Parametrik olmayan gruplar karşılaştırılırken ki-kare testi kullanıldı. Parametrik grupların karşılaştırılmasında ise student-t testi ve mann whitney u testi kullanıldı. Tüm istatistiksel analizler Statistical Package for the Social Sciences (SPSS) programı ile yapıldı. $P<0.05$ değeri istatistiksel anlamlı kabul edildi.

\section{ETIK KURUL ONAYI}

Tepecik eğitim ve araştırma hastanesi etik kurulundan onay alındı (12.05.2015/4-15)

\section{BULGULAR}

Çalışamaya 27 MGHOT hastası alındı. Nüks gelişen, gelişmeyen ve toplam hastaların klinik özellikleri ve demografik verileri tablo 1'de mevcuttur (Tablo 1).

Tablo 1: Hastaların klinik özellikleri

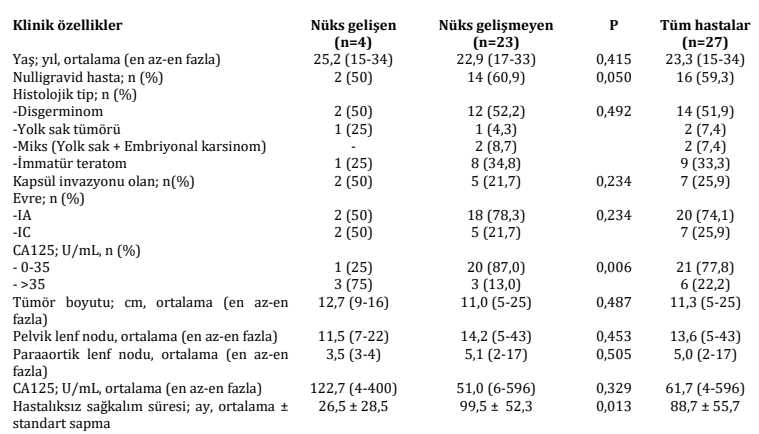

Hastaların 7 (\%25.9) tanesi sadece ameliyat olurken, 20 (\%74.1) hasta ameliyat sonrası adjuvan kemoterapi aldı. Hastalardan 4'üne (\%14.8) unilateral salfingo-ooferektomi, 21'ine (\%77.8) unilateral salfingo-ooferektomi + omentekto$\mathrm{mi}+$ pelvik paraaortik lenf nodu diseksiyonu, 2'sine (\%7.4) histerektomi + bilateral salfingo-ooferektomi + omentektomi ve pelvik paraaortik lenf nodu diseksiyonu işlemi yapıldı. 20 hastanın tamamı BEP protokolünü aldı. Hastaların 7 (\%35.0) tanesi 3 kür ve 13 (\%65.0) tanesi 4 kür tedavi aldı.
Hastaların 4 (\%14.8) tanesinde nüks gelişti. 2 (\%7.4) hastada diğer overe metastaz gelişirken, 1 (\%3.7) hastada diğer over + sigmoid kolona ve 1 (\%3.7) hastada iliak lenf nodunda nüks geliştiği saptandı. Nüks gelişme süreleri 8, 12, 17 ve 69. aylardı. Overlere nüks gelişen hastalara, rekürrens tedavisinde histerektomi + unilateral salfingo-ooferektomi işlemi yapıldı. Over + sigmoid kolon nüksü oluşan hastaya, rekürrens tedavisinde histerektomi + unilateral salfingo-ooferektomi işleminin yanısıra 4 kür BEP ve pelvik eksternal radyoterapi tedavisi verildi. İliak lenf nodu metastazı olan hastaya eksternal radyoterapi verildi. 5 yıllık hastalıksız sağkalım oranı \%88.9 olarak saptandı (Şekil 1).

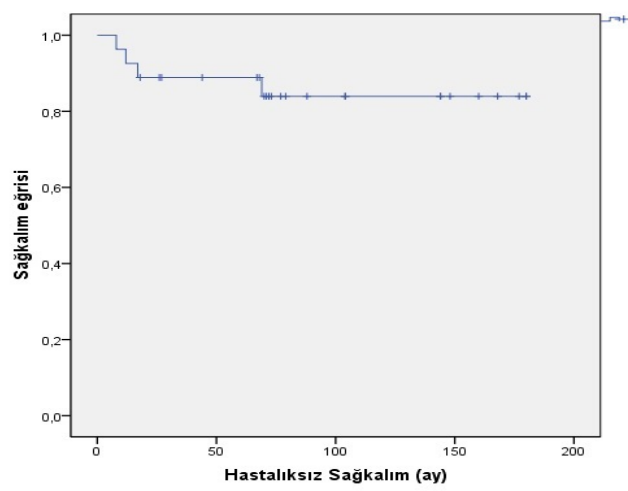

Şekil 1: Malign germ hücreli over tümöründe hastalıksız sağkalım eğrisi, Kaplan Meier

MGHOT olan hastalarda nüks görülme riskini öngörebilen faktörleri araştırmak için lojistik regresyon analizi yapıldı (Tablo 2 ) ve hastalıksız sağkalım süresine etki eden faktörler Cox-regresyon analizi ile araştırıldı (Tablo 3). CA125 değeri $>35 \mathrm{U} / \mathrm{mL}$, yaş $\geq 24$, lenf nodu örneklemesi yapılmayan hastalar, kemoterapi verilmeyen hastalar, tümör boyutu $>10 \mathrm{~cm}$ olan ve kapsül invazyonu olan hastalar değerlendirildi. Nüks oluşumuna veya hastalıksız sağkalım süresine etki eden prognostik faktörlerden; yüksek CA125 seviyesi (>35 U/mL) (Nüks oluşumu için $p=0.022$ ve hastalıksız sağkalım için $p=0.033$ ) ve kemoterapi verilmeyen (Nüks oluşumu için $p=0.022$ ve hastalıksız sağkalım için $p=0.029$ ) hastaların univaryant analizde istatistiksel anlamlı farklılığa sahip olduğu görüldü. Multivaryant regresyon analizinde yüksek CA125 $(p=0.998)$ ve kemoterapi verilmeyen hastaların $(p=0.997)$ nüks oluşumuna anlamlı etkisinin olmadığı bulundu. Hastalıksız sağkalım üzerine multivaryant Cox-regresyon analizine göre yük- 
sek CA125 ( $p=0.953)$ ve kemoterapi verilmemesinin $(p=0.872)$ anlamlı etkisinin olmadığı gösterildi.

Tablo 2: Evre I malign germ hücreli over tümörlerinde nüks gelişimine prognostik faktörlerin etkisi; Lojistik regresyon analizi

CA125 (>35 $\mathrm{U} / \mathrm{mL})$
Yas (224)
Lenfadenetomitom yaplmayan
Kemoterapi verilmeyen
Tümör boyutu ( $(10 \mathrm{~cm})$
Kapsuil invazyonu
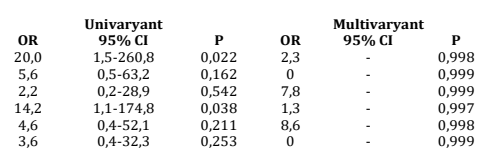

Tablo 3: Evre I malign germ hücreli over tümörlerinde hastalıksız sağkalım süresine prognostik faktörlerin etkisi; Cox-regrasyon analizi

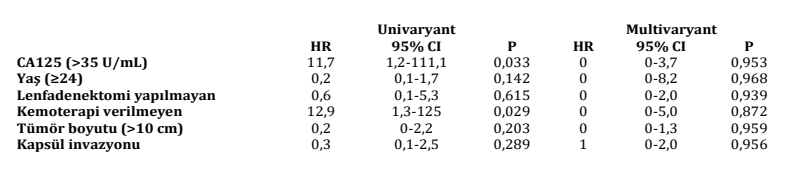

\section{TARTIŞMA}

Bu retrospektif çalışmada, evre I MGHOT tanılı 27 hasta araştırıldı ve nüks gelişimi ve hastalıksız sağkalıma etki eden prognostik faktörler incelendi. Germ hücreli tümörler, overin germinal hücrelerinden köken alan ve over tümörlerinin \%5'inden azını oluşturan disgerminom, yolk sak tümörü, immatür teratom ve daha az sıklıkta görülen grupları içerir (5). MGHOT'yi epitelyal tümörden ayıran tipik özellikleri; genelde onlu yada erken yirmili yaşlarda görülür, çoğu tanı sırasında evre I hastalığa sahiptir ve kemoterapiye duyarlılığından dolayı çok ilerlemiş hastalığı olanlarda bile prognoz mükemmeldir (5). Daha önce prognostik faktörleri araştıran çalışmalar mevcuttur. Bizim çalışmamızda evre I MGHOT hastalarının kemoterapi almaması ve yüksek CA125 seviyesi (>35 U/mL) nüks ve hastalıksız sağkalım üzerine negatif prognostik etkili olduğu univaryant regresyon analizi ile bulundu.

MGHOT hastaları tanı aldıklarında ortalama 1620 yaşlarında olduğu görülmüştür (1). En sık görülen malign germ hücreli tümör "Disgerminom"dur. Tüm germ hücreli tümörlerin \%40'ını oluşturur (5). Bilateral disgerminomda 5 yıllık sağkalım \%96 ve miks germ hücreli tümörü olanlarda \%87 olarak raporlanmıştır (4). MGHOT 5 yıllık hastalıksız ve toplam sağkalım oranları \%90.5 ve \%96.3 olarak saptanmıştır (4). Miks germ hücreli over tümörlerinde en sık görülen kombinasyon disgerminom ve yolk sac tümörüdür (6). Bizim çalışmamızda yaş ortalaması
23.3 ve en sık görülen tümör tipi disgerminom (\%51.9) olarak tespit edildi. Hastalıksız sağkalım süresi ortalama $88.7 \pm 55.7$ ay hesaplandı. 5 yıllık hastalıksız sağkalım oranı \%88.9 olarak saptandı. Bizim çalışmamızda tespit edilen 2 miks germ hücreli tümör yolk sak + embriyonel karsinom histolojik tipine sahipdi. MGHOT daha çok lenfatik peritoneal yüzeyler boyunca yayılırlar (5). Genellikle nükslerin ilk 24 ay içinde meydana geldiği gözlemlenmiştir (1.3). Bizim çalışmamızda nüks gelişen $\% 14.8$ hastanın; 2 (\%7.4) tanesinde diğer overe, 1 (\%3.7) tanesinde diğer over + sigmoid kolona ve 1 (\%3.7) tanesinde iliak lenf noduna metastaz yaptığı saptandı. Nüks gelişen hastaların, hastalıksız sağkalım süreleri 8, 12, 17 ve 69. aylardı.

Germ hücreli over tümörlerinde prognoza etki eden faktörlerin araştırılmasına rağmen nadir görülen tümörler olduğu için sonuçlarda çelişkiler bulunmaktadır. Kötü prognozla ilişkili faktörler, 45 yaş üstünde olmak, ileri evre, yüksek AFP ve HCG, inkomplet cerrahi rezeksiyon ve yolk sak histolojik tipe sahip olmakdır (1). Kistektomi işleminin nüks riskini arttırdığı bulunmuştur (7). Nüks gelişimi için risk faktörleri araştırılan çaIışmada ileri evre (evre III-IV) hastaların anlamlı farklılık gösteren riske sahip olduğu bulundu (6). Ancak yaş, histoloji, cerrahi tipi ve kemoterapi vermenin anlamlı farklılık göstermediği bulundu (6). Etkili kombine kemoterapi kullanımı, germ hücreli tümör prognozuna dramatik şekilde pozitif etki etmiştir (2). Vinkristin daktinomisin ve siklofosfamid (VAC) rejiminin evre I non-disgerminom tümörlerde $\% 86$ kür sağladığı, ancak metastatik hastalıkta \%50-70 mortaliteye neden olduğu gösterilmiştir (2). Bleomisin, etoposid ve sisplatin rejimi ile disgerminomda 5 yıllık sağkalım oranının \%100'e yakın ve non-disgerminomda \%85 olduğu bulundu (2). Platin bazlı kemoterapi verilen hastalarda toplam sağkalım oranı \%87-98 arasında olduğu bulundu (2). Toplam sağkalım üzerine ileri evre (IIIIV) ve yüksek serum AFP ve HCG seviyelerinin kötü prognostik etki gösterdiği ancak ileri yaşın prognoza etki göstermediği saptanmıştır $(8,9)$. Kim J ve ark yaptığı çalışmada, yüksek CA125 $(\geq 250 \mathrm{U} / \mathrm{mL}$ ) seviyesine sahip hastalarda, asit, over yüzey yayılımı, tümör rüptürü, büyük tümör boyutu $(>15 \mathrm{~cm})$ ve ileri evre olma ihtimalinin daha yüksek olduğu görülmüştür). Yüksek 
ve düşük CA125 seviyesine sahip gruplar arasında hastalıksız sağkalım sonuçlarının farklı olmadığı ancak toplam sağkalım süresinin yüksek CA125 seviyeli grupta anlamlı derecede kısa olduğu bulunmuştur (10). Hastalıksız sağkalımın tümör tipi (disgerminom - nondisgerminom) ve sitoredüksiyon tipi (maksimal - optimal) ile ilişkili olduğu gösterildi. Evre, lenfadenektomi ve koruyucu cerrahinin anlamlı etki etmediği gösterildi (3). Bizim çalışmamızda nüks gelişimini öngörebilmek için yapılan lojistik regresyon analizinde kemoterapi almayan hastalar ile CA125 seviyesi (>35 U/mL) yüksek olan hastaların anlamlı derecede risk faktörü olduğu bulundu. Aynı şekilde hastalıksız sağkalım süresine etki eden faktörlerin araştırıldığı Cox-regresyon analizinde kemoterapi verilmeyen hastalar ile yüksek CA125 seviyesinin istatistiksel anlamlı prognostik etki gösterdiği saptandı. Çalışmamızda multivaryant analizlerin hiçbir risk faktöründe anlamlı etki göstermediği saptanmasına rağmen sonucun az hasta ile yapılmasına bağlı olduğu düşünülmektedir. Ancak CA125 seviyesinin laboratuvarlarda eşik değeri olarak kabul edilen $35 \mathrm{U} / \mathrm{mL}$ ve üzerinde olmasının germ hücreli over tümöründe riski arttırdığına dair fazla veri görülemedi. Benzer şekilde LDH, AFP ve BHCG değerlerinin de karşılaştırılması planlanmasına rağmen retrospektif çalışmanın yapısı gereği hasta dosyalarından birçok hastanın söz konusu değerlerine ulaşılamadı.

Bu çalışmada bazı eksik yönler ve kısıtlamalar mevcuttur. En önemlilerinden bir tanesi, retrospektif çalışma tasarımının olmasıdır. Çalışmanın retrospektif doğası gereği, dosyalarda eksik olan bilgiler ve kayıtlarına ulaşılamayan sonuçlar bulunabilmektedir. Ek olarak, 18 yıl boyunca az sayıda hasta, farklı cerrahlar tarafından ameliyat edilmeleri ve farklı tedavi rejimleri kullanılması, karşılaştırmaları potansiyel olarak olumsuz yönde etkileyebilecek diğer sınırlayıcı faktörlerdendir. Bu kısıtlamalara rağmen, bizim çalışmamız, spesifik bir evre ile nadir görülen tümörde yapılan ve kısıtlı bir tedavi düzeninde yapıldığı için çalışmanın bulgularının değerini arttırmaktadır. Çalışma grubunda demografik veri ve klinik özellik açısından anlamlı farklılık olmaması, sonuçları daha güvenilir kılmaktadır.
Sonuç olarak, evre I malign germ hücreli over tümörüne sahip hastalarda yüksek CA125 değeri ve adjuvan kemoterapi verilmemesinin nüks gelişimini anlamlı derecede arttırdığı ve hastalıksız sağkalımı kısalttığı görülmektedir.

\section{Finansal destek veya çıkar çatışması}

Çalışmayı maddi olarak destekleyen kişi/kuruluş yoktur ve yazarların herhangi bir çıkar dayalı ilişkisi yoktur.

\section{KAYNAKLAR}

1. Brown J, Friedlander M, Backes F, ve ark. Gynecologic Cancer Intergroup (GCIG) Consensus Review for Ovarian Germ Cell Tumors. Int J Gynecol Cancer; 2014;24: 48-54.

2. Low J, llancheran A, Ng J. Malignant ovarian germ-cell tumours. Best Practice \& Research Clinical Obstetrics and Gynaecology; 2012; 26: 347-355.

3.Turkmen O, Karalok A, Basaran D, veark. Fertility-Sparing Surgery Should Be the Standard Treatment in Patients with Malignant Ovarian Germ Cell Tumors. Journal of Adolescent and Young Adult Oncology; 2017; 6: 270-276.

4. Zhao T, Liu Y, Jiang $H$, Zhang $H$ and LUY. Management of bilateral malignant ovarian germ cell tumors: Experience of a single institute. Molecular and Clinical Oncology; 2016; 5: 383-387.

5. Vazquez I and Rustin G. Current controversies in the management of germ cell ovarian tumours. Current Opinion Oncology; 2013; 25: 539-545.

6. Neeyalavira V and Suprasert P. Outcomes of Malignant Ovarian Germ-Cell Tumors Treated in Chiang Mai University Hospital over a Nine Year Period. Asian Pac J Cancer Prev; 2014; 15(12): 4909-4913.

7. Zhao T, Liu Y, Jiang $\mathrm{H}$, Zhang $\mathrm{H}$ and Lu Y. Management of bilateral malignant ovarian germ cell tumors: Experience of a single institute. Molecular and Clinical Oncology; 2016; 5: 383-387.

8. Murugaesu N, Schmid P, Dancey G, ve ark. Malignant ovarian germ cell tumours: identification of novel prognostic markers and long-term outcome after multimodality treatment. J Clin Oncol; 2006; 24: 48624866.

9. Lai $\mathrm{CH}$, Chang $\mathrm{TC}$, Hsueh $\mathrm{S}$, ve ark. Outcome and prognostic factors in ovarian germ cell malignancies. Gynacol Oncol; 2005; 96: 784-791.

10. Kim J, Park J, Kim J, Kim Y, Kim Y and Nam J. The role of preoperative serum cancer antigen 125 in malignant ovarian germ cell tumors. Taiwanese Journal of Obstetrics \& Gynecology; 2018; 57: 236-240. 